\title{
非対称な差動伝送線路からの電磁放射特性
}

\author{
萓野良樹*
}

\section{Electromagnetic Radiation from Asymmetrical Differential-Paired Lines}

Yoshiki KAYANO*

* 秋田大学 ( ( 010-8502 秋田市手形学園町 1-1)

*Akita University (1-1 Tegata-Gakuen-machi, Akita 010-8502)

\section{1. はじめに}

電子機器内の高速信号伝送方式には差動伝送技術が広く 用いられている ${ }^{1)}$ 。平行 2 線路の相対応する点の電流がど こでも大きさが等しく逆位相の場合, 線路は平衡状態にあ るといい, そうでない場合には不平衡状態にあるという 2)。 差動伝送方式は, 理想的な場合では 2 つの線路に等量異符 号の差動 (differential-mode: DM) 信号を励振するため, 線路 は平衡状態にあり, ノイズ放射が小さく, また同相 (common-mode: CM) ノイズに強い特徴がある。しかしなが ら, 現実にはビアなどとの接続のために生じる $2 つ の$ 線路 の不等長や, 屈曲や線路の隣接配線などに起因する幾何学 的な非対称が存在し，そのため，2つの線路を伝搬する信 号は完全な等量異符号ではなく, 振幅値, 基準電位, 位相 に差が発生する ${ }^{2), 3)}$ 。これは伝搬信号に不平衡・CM 成分が 生じたと考えることができる。また, 差動ドライバ出力の 不平衡や負荷の不平衡も $\mathrm{CM}$ 成分を生じる ${ }^{4) ~ 6) 。 C M}$ 成分 は強い電磁干渉 (Electromagnetic interference: EMI) を生じる ため, 伝送信号の品質の確保と同時に不要電磁波放射の解 決が重要な研究課題になっている。

レイアウトや対策法など差動伝送に関するさまざまな研 究がこれまでに行われてきているが, 信号の完全性 (Signal Integrity: SI) の観点から伝送特性およびモード変換につい て,または EMIの観点から電磁放射を個別に検討したもの が多い。そのため差動伝送線路において, アイパターンな どの信号の品質評価とともに不要電磁放射を扱った基礎的 な論文はまだ少なく, 両観点からの差動配線の設計技術, ガイドラインへの展開に関しても検討することが多い。

著者は, 根本的な解決のためには, 問題の発生を明確に するための単純化したモデルから, 基本現象を明らかに し, その現象を定量的に予測, 説明することを可能するた めの物理ベース等価回路モデルを開発することが必要不可 欠であると考えて，これまで検討を進めてきた ${ }^{711) 。 ~}$

本稿では, 非常に単純なレイアウトでありながら, SI 観 点で広く用いられているモード変換パラメータと放射 EMI
の相関関係が明確でない不等長モデルを対象に, 非対称構 造が $S$ パラメータ, 放射電磁界に与える影響を検討し, 等 価回路モデルにより支配的な放射要因を解析した例 ${ }^{9)}$ を示 し, 両観点での検討の重要性と等価回路解析の有用性につ いて紹介する。

\section{2. 検討モデル}

差動伝送線路上の非対称の原因には, IC ピンなどとの接 続のための不等長, グランドパターンや実装部品の線路付 近への配置, 屈曲部, 多層基板の複数層にわたる配線など が挙げられる。本研究では, IC のピンや BGA との接続の ために生じた不等長の問題を想定し，その位置の影響を明 確にするために，極端な不等長を生じさせるためのコの字 の屈曲部を設け，位置を変えたモデルを用いた。

検討に用いた不等長配線モデルを図 1 に示す。プリント 配線板は, マイクロ波回路において一般的に使用される 2 層 の表面マイクロストリップ線路 (S-MSL: Surface-Microstrip Line) 構造であり, 上面が信号配線, 下面が全面グランドで ある。寸法は, 長さ $l_{P C B}=137 \mathrm{~mm}$, 幅 $w_{P C B}=100 \mathrm{~mm}$, 誘 電体は厚み $h=1.53 \mathrm{~mm}$, 比誘電率 $\varepsilon_{r}=4.5$ の FR-4 基板を 用いた。

差動線路の平衡領域での差動間隔は $s=1.0 \mathrm{~mm}$ とし, 差 動インピーダンスが $Z_{D M}=100 \Omega$ になるように線路幅は $w_{t}=$ $1.9 \mathrm{~mm}$ とした。屈曲部の形状に関するコの字の間隔を 25 $\mathrm{mm}$, その位置に関係する屈曲部終点と基板端からの距離 $l_{x}$ を $12.5 \mathrm{~mm}, 37.5 \mathrm{~mm}, 62.5 \mathrm{~mm}$ と変えて検討した。

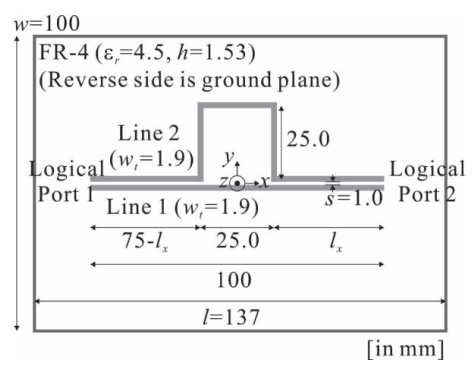

図 1. 幾何学的に非対称な不等長差動伝送線路モデル 


\section{3. 伝送特性とモード变換の周波数特性の評価}

伝送特性とモード変換を評価するために， 4 ポートネッ トワークアナライザを用いて, Mixed-mode S パラメータを $10 \mathrm{MHz} \sim 10 \mathrm{GHz}$ の周波数範囲で測定した。また, FDTD 法 による電磁界シミュレーションも行った。

Mixed-mode S パラメータは DM 成分, CM 成分をモード 別に表した S パラメータである。 DM (差動) 成分の透過 係数は, 論理ポート 1 に DM で入力したエネルギに対する 論理ポート 2 への DM での出力割合 $\left|S_{d d 21}\right|$ で表される。ま た CM (不平衡) へのモード変換透過係数は, 論理ポート 1 にDMで入力したエネルギに対する論理ポート 2 への CM での出力割合 $\left|S_{c d 21}\right|$ で表される。

差動成分の透過係数 $\left|S_{d d 21}\right|$ の周波数特性および差動から 不平衡成分である同相信号へのモード変換量 $\left|S_{c d 21}\right|$ の周波 数特性をそれぞれ図 2,3 に示す。参考比較のため, 線路長 が $100 \mathrm{~mm}$ の平衡線路についての特性も示す。ただし, 図 3 では平衡線路のためモード変換は理論的に生じず, 結果 はネットワークアナライザの背景雑音レベル (-60 dB 程度) のため省略している。

不等長の場合, $\left|S_{d d 21}\right|,\left|S_{c d 21}\right|$ ともに, 測定結果と計算結 果 $\left(l_{x}=37.5 \mathrm{~mm}\right.$ の場合のみ図示 $)$ はよく一致し， $l_{x}$ による 特性の違いは生じない。1.85 GHzの奇数整数倍の周波数 で, 透過係数 $\left|S_{d d 21}\right|$ では反共振が, モード変換量 $\left|S_{c d 21}\right|$ では 共振が生じている。これは $1.85 \mathrm{GHz}$ の奇数整数倍の周波数 では，不等長配線により完全に $\mathrm{CM}$ 一変換されて，DM と して伝送されないことを意味している。なお， $5 \mathrm{GHz}$ 以上

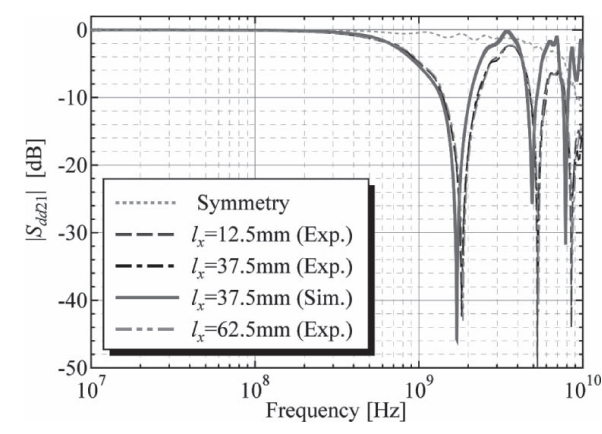

図 2. DM 成分の透過係数 $\left|S_{d d 21}\right|$ の周波数特性

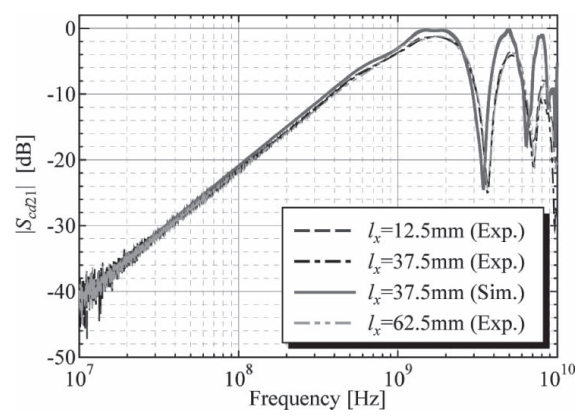

図 3. $\mathrm{DM}$ から CM へのモード変換係数 $\left|S_{c d 21}\right|$ の周波数特性
での劣化は，FR-4 基板の誘電体損に起因したものである。 モード変換の支配的な要因は単純な不等長による位相ズレ のため, モード変換量 $\left|S_{c d 21}\right|$ の周波数特性の低周波での傾 きは, $6 \mathrm{~dB} /$ Oct., つまり周波数に比例となる。

以上のように, 本不等長モデルにおけるモード変換 $\left|S_{c d 21}\right|$ は，不等長による位相ズレだけで決まり，不等長の場所に は依存しないことがわかる。

周波数特性をより詳細に理解するために, $\left|S_{d d 21}\right|$ の反共振 周波数, そして $\left|S_{c d 21}\right|$ の共振周波数である $1.85 \mathrm{GHz}$ での近 傍磁界の測定を行った。差動伝送線の始点 (Logical Port1) を水晶発振器 $(25 \mathrm{MHz})$ と LVDS ドライバ (NS DS90LV047A) で駆動し，終点(Logical Port2) を $100 \Omega$ で終端した。1.85 $\mathrm{GHz}$ は $25 \mathrm{MHz}$ の 74 次高調波であり, 配線の $2 \mathrm{~mm}$ 上の $H_{x}, H_{y}$ 成分を空間分解能 $250 \mu \mathrm{m}$ の磁界プローブで測定し, 実効值を算出した。各 $l_{x}$ の測定結果を図 4 に示す。



(a) $I_{x}=12.5 \mathrm{~mm}$

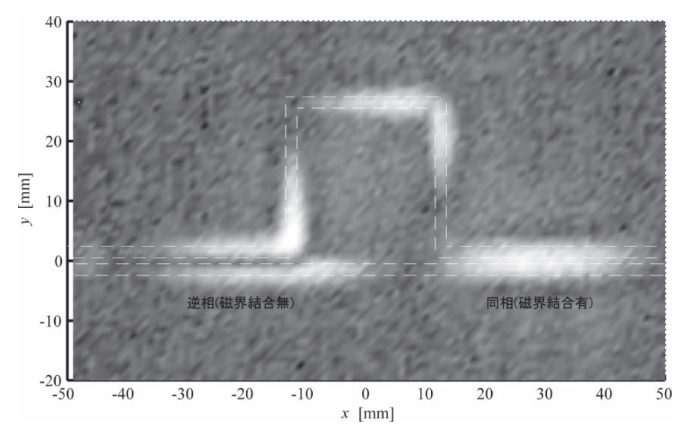

(b) $I_{x}=37.5 \mathrm{~mm}$



(c) $I_{x}=62.5 \mathrm{~mm}$

図 4. 線路の $2 \mathrm{~mm}$ 上の近傍磁界の強度分布 $(1.85 \mathrm{GHz}$, 測定結果) 
いずれの条件においても, 励振側 $(x=-50 \mathrm{~mm}$ 側 $)$ では 2 つの配線上の磁界は分離（配線間にヌル点がある）して いるのに対して，コの字領域後の負荷側 $(x=50 \mathrm{~mm}$ 側 $)$ で は2つの配線上の磁界は結合していることがわかる。これ は差動励振（電界で結合, 磁界結合無し）しているのにも 関わらず, $1.85 \mathrm{GHz}$ ではコの字領域による不等長のため, 終端部分では同相（磁界結合）で伝搬していることを意味 しており, 図 2,3 の Mixed-mode S パラメータの周波数特 性の共振, 反共振特性と対応している。

\section{4. 放射特性の評価と等価回路モデルによる支配的要 因の識別 ${ }^{9), 11}$}

著者らは，各領域からの放射電界のベクトル和によって 観測点での全放射電界強度を求める物理ベース等価回路モ デルを提案し, 線路の各位置, マクロ的には各断面構造の 全放射電界強度に対する寄与の分離識別を可能とすること で, 差動伝送線路中の支配的な放射要因を明らかにするこ とを試みている ${ }^{9), 11) 。 ~}$

放射電磁界は電流および磁流分布から算出できる。図 1 の幾何学的に非対称な不等長差動伝送線路モデルでは, ス ロットや平行平板構造はないため, 電流分布のみを考慮す れば良い。図 5(a) に示すように結合線路部分 (a,b, c,) とマ イクロストリップ線路部分 $(\mathrm{d}, \mathrm{e})$ の領域に区分した。

放射要因として，要因 1) 非対称による $\mathrm{CM}$ 伝搬部分の発 生による CM 放射の増加, 要因 2) 差動伝送線路間隔の広が りによる差動信号のメリットである放射打ち消し効果の減 少, 要因 3) グランド幅が狭い基板や部品配置のために差動 線路が基板端に配線したことにより，線路を流れる信号電

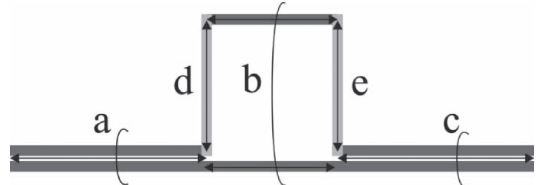

(a) 差動伝送線路の領域区分

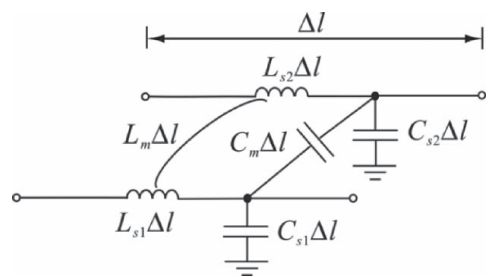

(b) 結合線路部分の等価回路モデル（1 段分）



(c) マイクロストリップ線路部分の等価回路モデル（1 段分）

図 5. 放射予測のための回路モデルの領域分割
流とグランド面のリターン電流のバランスが崩れたことに よる $\mathrm{CM}$ 放射の増加 ${ }^{12), 13)}$ ，の 3 つが考えられる ${ }^{8), 9), 11) 。 ~}$

本稿では差動伝送線路からの電磁放射特有の問題である 要因 1 と要因 2 の影響を明確にするために, 無限幅のグラ ンド面上に配線された場合を想定して，等価回路解析を 行った。各領域は微小区間 $\Delta l$ の等価回路の縦続接続でモデ ル化した。微小区間（1 段あたりの長さ） $\Delta l$ は，波長短縮 効果を考慮した測定最高周波数 $10 \mathrm{GHz}$ の波長の $1 / 20$ 以下 になるように $\Delta l=0.25 \mathrm{~mm}$ とした。なお，等価回路におい て，コの字部分の間隔は $25 \mathrm{~mm}$ と広いため, d-e 間の電磁 結合は無視した。表 1 に, 2 次元断面の電磁界解析により 算出した等価回路パラメータを示す。

図 6 に線路 1,2 を振幅 $1 \mathrm{~V}$, 位相差 $180^{\circ}$, 周波数 $1.85 \mathrm{GHz}$ の差動信号で励振した時の電流分布を示す。ただし，位相 情報を明確にするために，図 4 のような実効值ではなく， 励振後から $t=1.5 \mathrm{~ns}$ 後の瞬時值を示している。図 2 4の 議論と同様に，本周波数ではコの字による不等長部分より 後半の伝搬は同相になっているのが明確にわかる。

図 7 に $l_{x}=37.5 \mathrm{~mm}$ の場合の等価回路モデルによる放射 解析結果を示す。本図中では, 線路への入力電圧 (実効值) が $1 \mathrm{~Hz}$ 当たり $107 \mathrm{~dB} \mu \mathrm{V}$ 一定となるように正規化し，放射 効率の観点から議論した。図中の凡例“Total (FDTD)” の 線は，FDTD 法によるフルウェーブ解析した差動伝送線路 全体から放射された電界強度值である。凡例“Total (Equiv.)”は等価回路モデルにより計算した, 差動伝送線路

表 1. 放射予測のための等価回路モデルの回路定数 (a) 結合線路領域

\begin{tabular}{c|c|c|c|c|c|c|c}
\hline 領域 & $\begin{array}{c}s \\
{[\mathrm{~mm}]}\end{array}$ & $\begin{array}{c}L_{s 1,2} \\
{[\mathrm{nH} / \mathrm{m}]}\end{array}$ & $\begin{array}{c}L_{m} \\
{[\mathrm{nH} / \mathrm{m}]}\end{array}$ & $\begin{array}{c}C_{s 1,2} \\
{[\mathrm{pF} / \mathrm{m}]}\end{array}$ & $\begin{array}{c}C_{m} \\
{[\mathrm{pF} / \mathrm{m}]}\end{array}$ & $\begin{array}{c}Z_{D M} \\
{[\Omega]}\end{array}$ & $\begin{array}{c}Z_{C M} \\
{[\Omega]}\end{array}$ \\
\hline $\mathrm{a}, \mathrm{c}$ & 1.0 & 366 & 90 & 86 & 15 & 100 & 36.3 \\
\hline $\mathrm{b}$ & 26 & 369 & 43 & 98 & 0.061 & 125 & 31.2 \\
\hline
\end{tabular}

(b) マイクロストリップ線路領域

\begin{tabular}{c|c|c|c}
\hline 領域 & $\begin{array}{c}L_{s} \\
{[\mathrm{nH} / \mathrm{m}]}\end{array}$ & $\begin{array}{c}C_{s} \\
{[\mathrm{pF} / \mathrm{m}]}\end{array}$ & $\begin{array}{c}Z_{0} \\
{[\Omega]}\end{array}$ \\
\hline $\mathrm{d}, \mathrm{e}$ & 363 & 100 & 60 \\
\hline
\end{tabular}

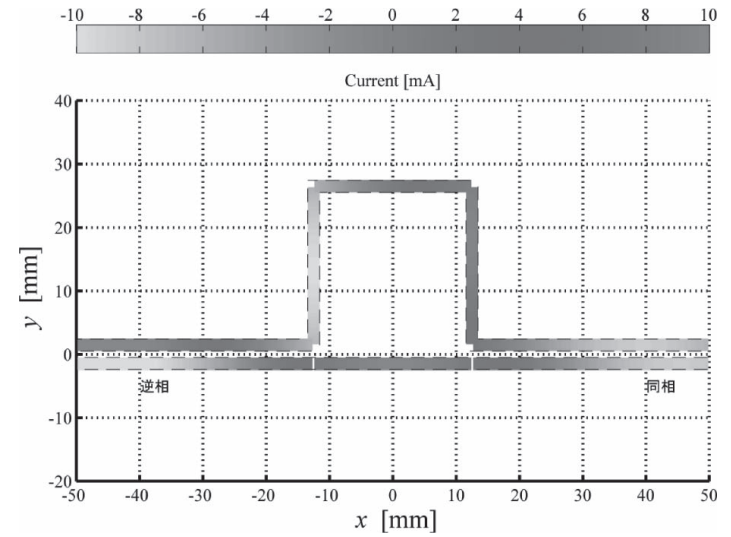

図 6. 等価回路モデルから得られた電流分布 $(1.85 \mathrm{GHz}$ の 差動信号励振, $t=1.5 \mathrm{~ns}$ の瞬時値) 


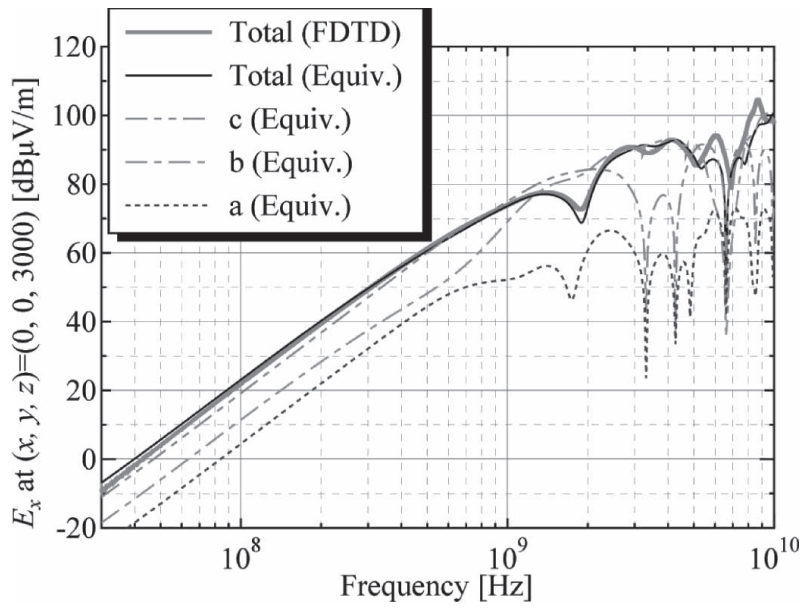

図 7. $I_{x}=37.5 \mathrm{~mm}$ の場合の等価回路による支配的な放射 要因の識別

全体から放射された電界強度值である。そして，凡例“a” から“c”の線は等価回路モデルにより計算した, 区分した 各領域からの放射電界強度值である。なお, 差動伝送線路 全体からの放射強度值 (Total) は, 各領域部分の 1 段当たり の等価回路から求めた成分のべクトル和であるため, 位相 の関係で各領域からの放射電界強度值が Total を超える場合 がある。

各要因の影響を議論する前に, 全放射成分の FDTD 計算 結果と等価回路解析結果を比較すると, 両者はよく一致し ており，提案するモデルが妥当であることが確認できる。

次に各領域の等価回路解析結果を比較すると, $1 \mathrm{GHz}$ 以 下の低周波帯では Total と領域 c からの放射電界強度が一致 することから, 要因 1 が支配的な放射要因である。そし て, $2 \mathrm{GHz}$ 超高周波では領域 $\mathrm{b}$ からの放射電界が Total の包 絡線と一致することから, 要因 2 が支配的な要因である。 提案する等価回路モデルによる解析は, 支配的な放射要因 を定量的に識別することが可能である。本稿では周波数特 性の議論に焦点をあてたが，等価回路解析は，設計のため の定量的な指針となる線路間隔, 位相差, 放射強度を関係 付けることもできる ${ }^{11)}$

図 8 に $l_{x}=12.5,37.5,62.5 \mathrm{~mm}$ の電磁放射の等価回路解析 結果を示す。図 3 のモード変換量 $\left|S_{c d 21}\right|$ とは異なり, 低周 波では $l_{x}$ が長いほど放射が増加する。図 7 での各要因解析 の結果から, $1 \mathrm{GHz}$ 以下では $l_{x}$ が長い程, 最初の屈曲部で 発生した不平衡により，電流が同相（磁界結合）で伝搬す る領域 c が増えるため, ダイポールアンテナの形成により 強い電磁放射が生じることがわかり，2 GHz 以上では要因 2 (領域 $\mathrm{b}$ ) の影響が大きくなるため, 放射は $l_{x}$ にあまり依 存しないことが明確に理解できる。

以上の結果は, モード変換係数 $\left(S_{c d 21}\right)$ のみでは放射の定 量的な評価が行えないこと, そして, 従来から信号品質改 善の観点から広く利用されているミアンダ遅延線などの等 長配線は, 伝送線路終端での不平衡成分を抑制し信号伝送

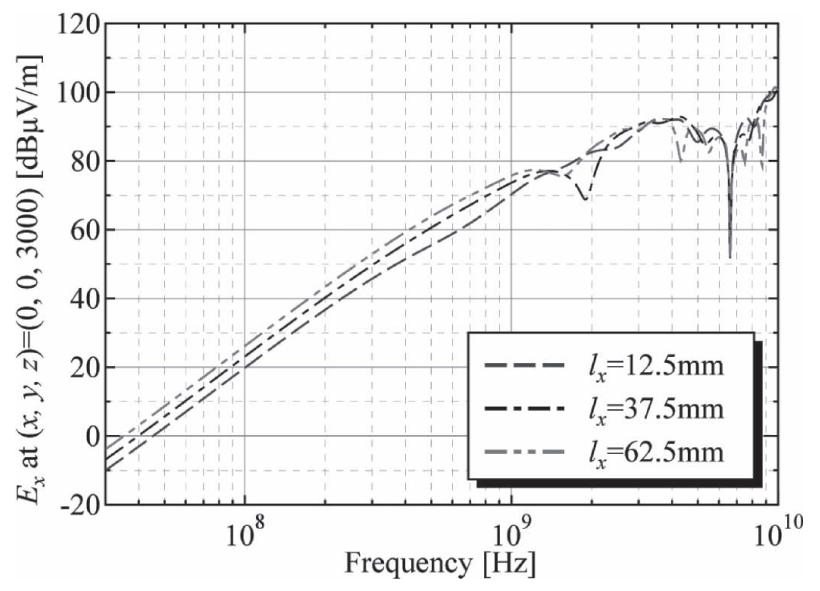

図 8. 電磁放射の等価回路解析結果

に関する信号品質の確保には有効であるが，位相補償前の 領域で要因 1 による強い放射が生じるために放射そのもの の抑制にはあまり効果的ではないことも示唆している ${ }^{11)}$ 。

\section{5. おわりに}

本稿では，幾何学的に非対称な不等長差動伝送線路に関 して, 非対称構造が $S$ パラメー夕，放射電磁界に与える影 響を検討し，等価回路モデルにより支配的な放射要因を解 析した例を紹介した。今回の不等長配線では，モード変換 $\left|S_{c d 21}\right|$ は位相ズレが発生する位置には依存しないが, 位相ズ レの領域が大きくなるほど電磁放射が増加した。実際の配 線レイアウトにおいては，配線間隔を最優先にして始点部 分での位相ズレを補償しない場合もあり，EMIの問題はよ り顕在化すると考えられる。本結果は, SI, EMIの両観点 から配線設計を行うことの重要性と，レイアウト上の制限 はあるものの放射 EMI を抑制するためには，位相補償は可 能な限り位相ズレ箇所の近くで行わなければならないこと を定量的に示したものである。本結果を差動配線のSI およ びEMI 設計に取り入れつつ，線路終端部分での位相補償に 代わる対策, 設計ガイドラインの開発が今後の課題である と思われる。

\section{謝 辞}

本研究を進めるにあたり，電波暗室での電磁放射の測定 に御協力頂きました秋田県産業技術センター, FDTD 計算 におけるスーパーコンピュータの利用に関して御協力頂き ました東北大学サイバーサイエンスセンターに深く感謝致 します。

本解説記事の成果の一部は, JSPS 科研費 26820091 の助 成を受けたものである。

最後に, 日頃から御助言をいただく放送大学秋田学習セ ンター所長井上浩先生, 電磁特性技術委員会の皆様に感謝 の意を表します。

(2015.6.28- 受理) 


\section{文献}

1) S. Hall, G. W. Hall, and J. A. McCall: "High-Speed Digital System Design: A Handbook of Interconnect Theory and Design Practices," John Wiley \& Sons, INC., New York, 2000

2) 内田英成, 虫明康人：“超短波空中線, ”第 7 章, コロナ 社, 1955

3）中西秀行：“差動伝送路の設計と信号品質,” Vol. 16, No. 3, pp. $181-186,2013$

4) 回路・実装設計技術委員会 : “システムJisso-CAD/CAEの 課題と展望, ”エレクトロニクス実装学会誌, Vol. 17, No. 1, pp. 6-11, 2014

5）上 芳夫：“差動伝送の基礎,” エレクトロニクス実装学会 誌, Vol. 16, No. 3, pp. 176-180, 2013

6) F. Grassi, G. Spadacini, and S. A. Pignari: "The concept of weak imbalance and its role in the emissions and immunity of differential lines," IEEE Trans. Electromagn. Compat., Vol. 55, No. 6, pp. 1346-1349, 2013

7) Y. Kayano and H. Inoue: "Identifying EM Radiation from a Printed-Circuit Board Driven by Differential-Signaling," Trans. JIEP, Vol. 3, No. 1, pp. 24-30, Dec. 2010

8) Y. Kayano, K. Mimura, and H. Inoue: "Evaluation of Imbalance Component and EM Radiation Generated by an Asymmetrical Differential-Paired Lines Structure," Trans. JIEP, Vol. 4, No. 1, pp. 6-16, Dec. 2011

9) Y. Kayano, Y. Tsuda, and H. Inoue: "Evaluation of Imbalance Component and EM Radiation from Asymmetrical Differential-
Paired Lines," in Proc. International Conference on Instrumentation, Control and Information Technology (SICE2012), pp. 422-427, Akita, Japan, Aug. 2012

10) Y. Kayano, M. Ohkoshi, T. Watabe, and H. Inoue: “Locally Shielded Differential-Paired Lines with Bend Discontinuities for SI and EMI Performances," Trans. JIEP, Vol. 7, No. 1, pp. 32-38, Dec. 2014

11) Y. Kayano and H. Inoue: "Dominant Factors of EMI Problems of Asymmetrical and Equi-Distance Differential-Paired Lines," Radio Science, 50, doi:10. 1002/2014RS005507, pp. 111-121, Feb. 2015

12) Y. Kayano, M. Tanaka, J. L. Drewniak, and H. Inoue: “CommonMode Current due to a Trace Near a PCB Edge and Its Suppression by a Guard Band,” IEEE Trans. Electromagn. Compat., Vol. 46, No. 1, pp. 46-53, Feb. 2004

13) F. Xiao, K. Murano, M. Tayarani, and Y. Kami: "Electromagnetic Emission from Edge Placed Differential Traces on Printed Circuit Board," in Proc. Int. Symp. EMC, Sendai, pp. 29-32, Jun. 2004

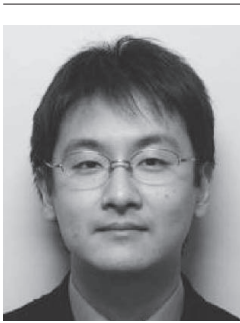

萓野良樹（かやの よしき）

木更津高専・電気卒 ('99 年)。秋田大学鉱山学 部卒 ('01 年)。同大学大学院工学資源学研究科博 士後期課程修了 ('06 年)。同年秋田大学・助手。 現在, 講師。プリント配線板, 電気接点の $\mathrm{EMC}$ 問題に関する研究に従事。IEEE, 電子情報通信学 会会員。 